\title{
The phacopine trilobite genera Morocops Basse, 2006 and Adrisiops gen. nov. from the Devonian of Morocco
}

\author{
AlLART VAN VIERSEN, DieTER HOLLAND \& JeNS KOPPKA
}

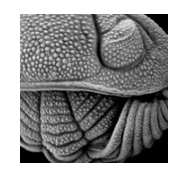

\begin{abstract}
Well-preserved specimens of the phacopine trilobites Morocops Basse (= Barrandeops McKellar \& Chatterton) and Adrisiops gen. nov. are recorded from upper Emsian strata in Morocco. Morocops is a problematic taxon; the close similarities of its stratigraphically youngest members to the earliest members of Geesops Struve are indicative of grade taxonomy. So far, Morocops is exclusively Gondwanan although potential congeners have been described from peri-Gondwana. One of the stratigraphically oldest species of Geesops occurs in the lower Eifelian of the French Ardennes (Laurussia). Its co-occurrence with pioneer "Bohemian" trilobites there suggests that faunal exchange between Laurussia and peri-Gondwanan terranes was unhindered at that time. New material of Morocops torkozensis (Schraut) is recorded; however, the type locality and horizon of this species remain uncertain. Adrisiops gen. nov. is erected to accommodate strongly vaulted, Gondwanan taxa that share a unique cephalic morphology inclusive of a short, but rather inflated glabella and ventrally deflected anterior border. New taxa are Morocops spinifer sp. nov. and Adrisiops weugi gen. et sp. nov. $\bullet$ Key words: Trilobita, Phacopidae, taxonomy, palaeobiogeography, Morocco, Algeria, Emsian, Eifelian.
\end{abstract}

Viersen, A.P. VAN, Holland, D. \& KoPPKA, J. 2017. The phacopine trilobite genera Morocops Basse, 2006 and Adrisiops gen. nov. from the Devonian of Morocco. Bulletin of Geosciences 92 (1), 13-30 (8 figures). Czech Geological Survey, Prague. ISSN 1214-1119. Manuscript received June 10, 2016; accepted in revised form January 25, 2017; published online February 20, 2017; issued March 31, 2017.

Allart P. van Viersen, Natuurhistorisch Museum Maastricht, de Bosquetplein 6-7, 6211 KJ Maastricht, the Netherlands; apvanviersen@gmail.com•Dieter Holland, Sandstrasse 26, 31241 Ilsede, Germany; dihol@t-online.de•Jens Koppka, Rue des Malvoisins 14, 2900 Porrentruy, Switzerland; jenskoppka@ gmail.com

For over a century the vast majority of late Early to Middle Devonian members of the subfamily Phacopinae had been attributed to a single genus, Phacops Emmrich, 1839, until extensive splitting started in the 1970s (e.g., Chlupáč 1971, Struve 1972). Opinions on the systematics of Phacops and similar taxa probably could not have diverged more widely since. Struve erected most of the new genera that are morphologically close to Phacops. While some workers have generally followed his concept (e.g., Bruton \& Haas 1997; Basse 1998, 2006; Jell \& Adrain 2002; van Viersen 2007), others have treated Phacops in a very broad sense (e.g., Campbell 1977; Chlupáč 1977; Schraut 2000a, b). Apart from these divergent viewpoints the genus Phacops continues to serve as a convenient wastebasket taxon for placement of phacopines that cannot be assigned to any other genus with certainty.

McKellar \& Chatterton (2009, p. 25) eloquently outlined the basic problem with the classification of Phacopinae as, "a moderate amount of homoplasy in an enormous, partially represented set of taxa, with relatively conservative overall morphology restricting the number of characters available for comparison". Indeed, in view of the difficult character appraisals, the study of phacopines, more than for most other trilobite groups, has become a rather subjective matter depending on a worker's experience and opinion. McKellar \& Chatterton (2009) performed a cladistic analysis of selected Phacopinae with the emphasis on Emsian to Givetian taxa from Morocco and laid down a useful foundation for future analyses along with suggestions as to how to proceed further. In the Ardenno-Rhenish Mountains, the type area of many classic species and the main geographical scope of Struve's work, the current state of Devonian phacopine affairs was comprehensively captured by Basse (2006). Basically, he adopted and updated Struve's classifications; however, with the explicit incentive of letting other workers elaborate further on these. Important papers covering other geographical areas in western Europe and northern Africa include those of Morzadec (1969), Chlupáč (1977), Smeenk (1983), Basse (1998) and Khaldi et al. (2016).

The present note is part of a series of papers that aim to contribute to the knowledge of phacopine diversity in the closing Rheic Ocean during the Early and Middle Devonian (van Viersen et al. in press). Here, we treat the genera 


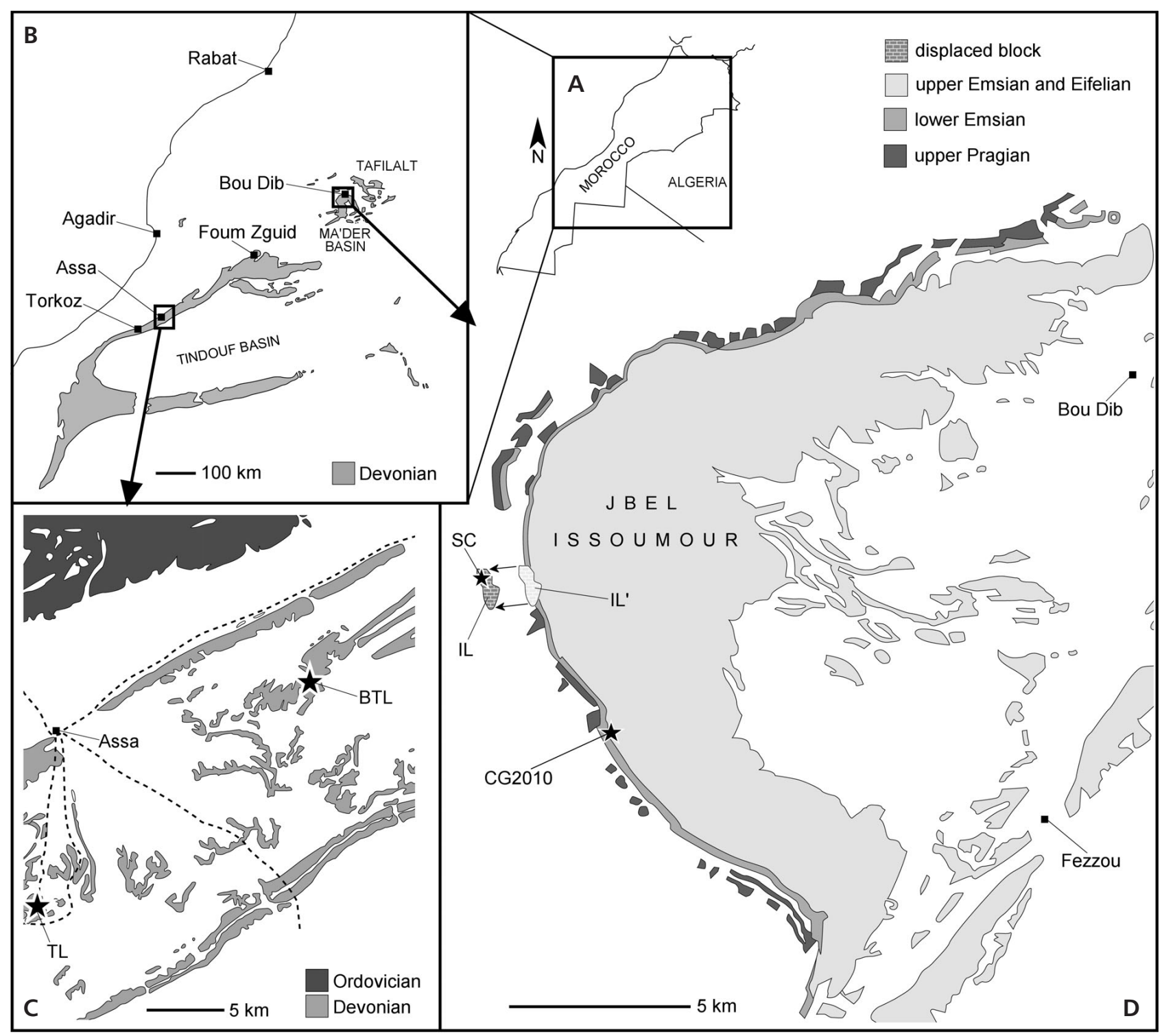

Figure 1. Maps of A - Morocco with rectangle indicating the extent of the study area. $\bullet$ B - central and eastern Morocco showing locations of sections. $\bullet$ C - Assa region, western Draa Valley with the Tadachacht (TL) and Bou Tserfine (BTL) localities indicated. $\bullet$ D - Jbel Issoumour with the isolated hill (IL), its putative original position (IL'), the source of the trilobites from the 'smiley Phacops couche' (SC) and the Issoumour locality of Chatterton \& Gibb (2010) (CG2010).

Morocops Basse, 2006 and Adrisiops gen. nov., both of which encompass species from Morocco and Algeria.

\section{Geological and stratigraphic setting}

Devonian sediments are exposed in southern Morocco over a distance of nearly $500 \mathrm{~km}$. Outcrops well known for their exquisitely preserved trilobites are located in the Tindouf, Ma'der and Tafilalt basins (Fig. 1). Two of the three localities studied are situated in the western Draa Valley, Tindouf Basin; the third is located near Jbel Issoumour, Ma'der Basin.
Locality Bou Tserfine. - Co-ordinates N 28 39'11.80", W 9 $9^{\circ} 16^{\prime}$ 5.60", western Draa Valley, Tindouf Basin (Fig. 1C). The base of the Khebchia Formation (upper Emsian) comprises a 5-6 metres thick alternation of marly limestones and marly shales (Fig. 2). This interval is a regional marker that was described as the Hollardops Limestone Member by Becker et al. (2004c), who considered it to be a regressive unit at the putative end of the regional sedimentary cycle 3. Becker et al. (2004b) and Brett et al. (2012) studied the macrofauna of the Khebchia Formation at Bou Tserfine and mentioned an abundance of the trilobites Hollardops mesocristatus (Le Maître, 1952) and Phacops. One of us (DH) collected enrolled specimens of 


\section{Bou Tserfine}
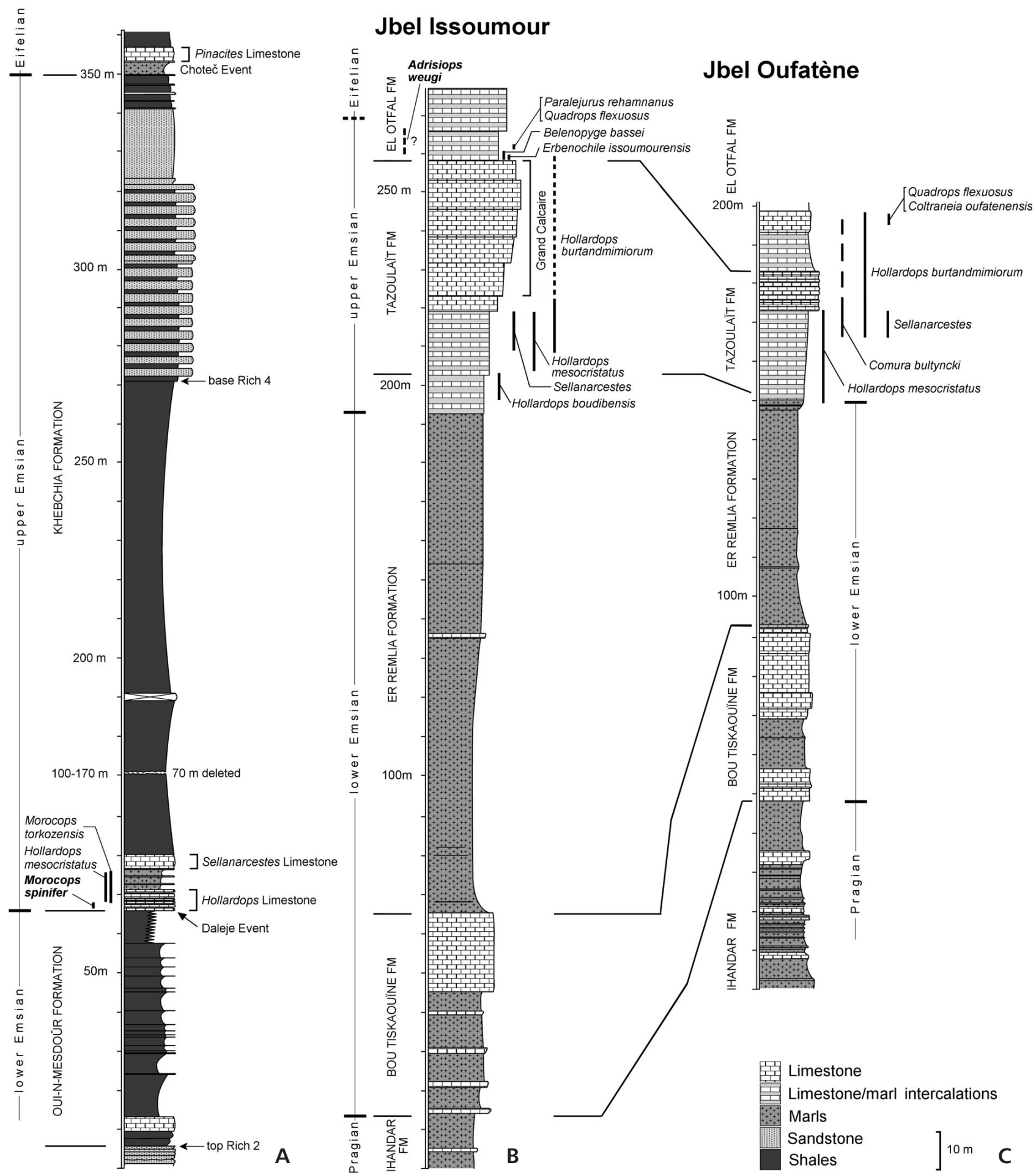

Figure 2. Lithostratigraphic columns of the A - Bou Tserfine section, modified and simplified from Becker et al. (2004b). B - Jbel Issoumour section, modified and simplified from Morzadec (2001) and Chatterton \& Gibb (2010). • C - Jbel Oufatène section, modified and simplified from Morzadec (2001). Putative chronostratigraphic borders after Aboussalam et al. (2015) and trilobites, in part, after Brett et al. (2012). Authorship of trilobite species not mentioned elsewhere in the present note is as follows: Paralejurus rehamnanus Alberti, 1970, Erbenochile issoumourensis Chatterton \& Gibb, 2010 and Hollardops boudibensis Morzadec, 2001. 


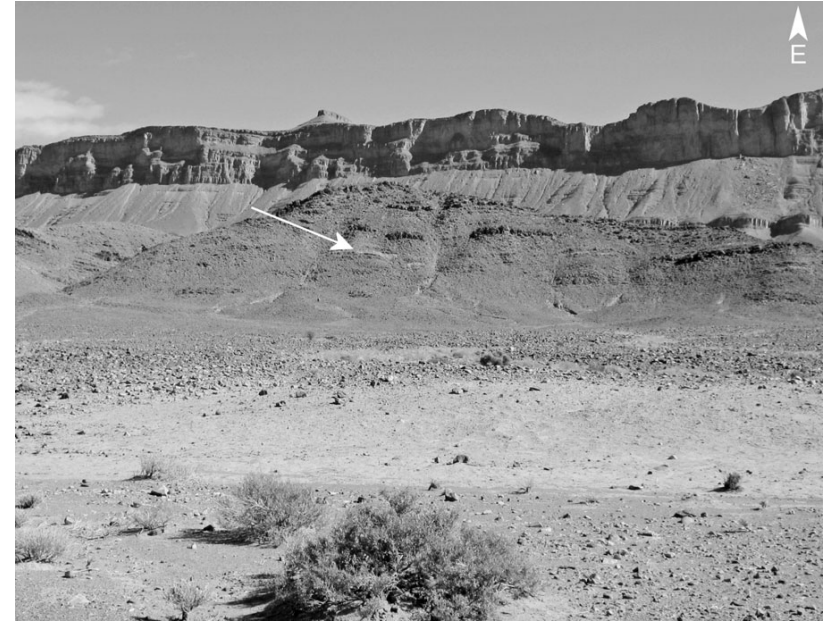

Figure 3. Photograph of the Issoumour locality (taken by DH in 2012). The elongated hill in front is the origin of the trilobites. In the background is the western cliff of Jbel Issoumour showing the near-vertical escarpment of the "Grand calcaire". The arrow indicates the source of the holotype of Adrisiops weugi gen. et sp. nov.

Morocops spinifer sp. nov., which often occur together, from several levels low in the Hollardops Limestone Member. A large specimen of M. spinifer sp. nov. (NHMM 2016 004) was recovered from a sandy, biodetritic marly layer with high tentaculite content near the base of this unit. A second, smaller, conspecific specimen (NHMM 2016 005) comes from compacted marls, 1 metre above the previous.

Brett et al. (2012) studied the Bou Tserfine section and suggested that the occurrences of enrolled trilobites and well-preserved and uncompressed in situ macrofauna pointed to periodic mudflow events that led to their rapid burial. Extensive bioturbation is indicative of periods of sediment starvation; trilobites are very rare here.

Locality Tadachacht. - $12.5 \mathrm{~km}$ south of the village centre of Assa, western Draa Valley (Fig. 1C). This site was described by van Viersen \& Holland (2016), who provided a list of trilobite species occurring here. A specimen of $\mathrm{Mo}$ rocops torkozensis (Schraut, 2000a) was collected by one of us (DH) from marls in the upper part of the Hollardops Limestone Member (Khebchia Formation). A log of this locality is not available, but that particular member is a comparatively thin, characteristic regional marker that was described from the nearby locality of Bou Tserfine. Thus, the origin of our specimen of M. torkozensis is sufficiently well known.

Locality Issoumour. - Co-ordinates N $31^{\circ} 0^{\prime} 44.66^{\prime \prime}$, W 5 $4^{\circ} 2.81^{\prime \prime}, 15 \mathrm{~km}$ east of Alnif, Ma' der Basin (Fig. 1D). This is an elongated ( $1 \mathrm{~km}$ long) isolated hill surrounded by large masses of alluvium. It is located in a small valley, $1.5 \mathrm{~km}$ off the base of the western slope of Jbel Issoumour.
The section comprises a $c .20$ metres thick marly unit with intercalated limestone beds of varying thickness; these generally become thicker and more numerous in the upper (eastern) part of the hill. The zone is marked on the geological map of the Ma'der Basin (Dresnay et al. 1988) as "di3", which corresponds to the "Calcaires noirs noduleux de la Corniche moyen de Issemour". According to the map, trilobites such as Zlichovaspis cf. auriculata (Dalman, 1826) and Devonodontochile maccoyi (Barrande, 1852) are characteristic of marly unit "di3" with nodular black limestones and suggest an early Emsian (Zlichovian) age. However, the trilobite association discovered at the above-mentioned hill differs both in composition and age.

The trilobites (data from DH, JK and Mohamed Koumali) come from a yellowish to grey crinoidal limestone layer (informally referred to as 'smiley Phacops couche', after the occurrence of 'smiley Phacops' = Adrisiops weugi gen. et sp. nov.) from the northwestern part of the hill (Fig. 3), in the basal part of the section. Frequent species are Coltraneia cf. oufatenensis Morzadec, 2001 and Adrisiops weugi gen. et sp. nov. Comparatively rare species include Acastoides sp., Belenopyge sp., Cornuproetus sp., Hollardops burtandmimiorum (Lieberman \& Kloc, 1997), Quadrops cf. flexuosus Morzadec, 2001 and a single Comura cf. bultyncki Morzadec, 2001 is known. This trilobite association is characteristic of the lower (upper Emsian) part of the El Otfal Formation. Chatterton \& Gibb (2010) described a similar association from the 'Erbenochile couche', in the basal part of that formation, at Jbel Issoumour in a section $5 \mathrm{~km}$ south of ours (Fig. 1D). Species such as Hollardops burtandmimiorum and Belenopyge bassei (Chatterton \& Gibb, 2010) occur in and slightly above the 'Erbenochile couche'. In addition, Quadrops flexuosus has recently been found in the slightly stratigraphically higher 'Paralejurus couche' of Chatterton \& Gibb (2010) (Mohamed Koumali, pers. comm., April 2016). A decade earlier, Morzadec (2001) had recorded a trilobite association similar to ours from the lower part of the El Otfal Formation at Jbel Oufatène (Fig. 2C), $30 \mathrm{~km}$ south of Jbel Issoumour. Morzadec (2001) also recorded Comura bultyncki, Coltraneia oufatenensis and Quadrops flexuosus; these were not mentioned by Chatterton \& Gibb (2010) from Jbel Issoumour.

Another clue about the age of the 'smiley Phacops couche' comes from two undescribed species of Cyphaspis, which were also discovered at our Issoumour locality. These are members of the Cyphaspis hamidi and Cyphaspis agayuara groups of van Viersen \& Holland (2016), respectively. According to those authors, the stratigraphically earliest known members of the hamidi group come from just below the lower-upper Emsian boundary. They also noted that co-occurrences of hamidi and agayuara group members are widespread in upper Emsian strata of Gondwanan and peri-Gondwanan origin. 
The final piece of evidence comes from the occurrence of Adrisiops gen. nov.; all other species of this genus that are known to us (see assigned species below) stem from confirmed upper Emsian and Eifelian strata in Morocco and Algeria.

In summary, we believe that the trilobite association suggests a late, rather than an early, Emsian age. In all probability the 'smiley Phacops couche' can be correlated with a level that is near the base of the El Otfal Formation, close to the Emsian-Eifelian boundary. Given the absence of similar trilobite associations at the base of Jbel Issoumour, which are generally stratigraphically older ( $\mathrm{Si}$ lurian to Pragian), we suspect that the elongated hill is a displaced block; i.e., the result of a large landslide which may have occurred during a humid phase in the Quaternary or, less probably, it could be the result of local tectonics. This view is supported by the numerous small-scale faults interrupting the outcrop, and furthermore by the restricted lateral distribution and unusually steep inclination of the beds $\left(c .45^{\circ}\right)$. The 'in situ' strata of Jbel Issoumour show little tectonic disturbance and rarely a $>10^{\circ}$ inclination towards the east. The putative original position of the displaced block (Fig. 1D) is more than $200 \mathrm{~m}$ higher up, directly above the "Grand Calcaire" cliff of Jbel Issoumour, where upper Emsian limestones form a $c .70$ metres tall escarpment (Fig. 3). A marly unit with intercalated limestone beds overlies the massive limestones of the "Grand Calcaire" and corresponds well with the lithology of the displaced block.

Notes. - According to the International Code of Zoological Nomenclature (article 30.1.4.3) a compound genus-group name ending in "-ops" is to be treated as masculine, regardless of its derivation or of its treatment by its author. Consequently, we change the names Quadrops flexuosa and Hollardops mesocristata into Q. flexuosus and H. mesocristatus, respectively.

Another incorrect spelling concerns Philipsmithiana burtandmimiae, described by Lieberman \& Kloc (1997, pp. 68-69, figs 7.2-6, 8; 21.1, 3, 4; 22.3, 4, 7, 10, 12, 13) to honour Burt and Mimi Lieberman (the parents of Bruce $S$. Lieberman), and transferred by Morzadec (2001) to Hollardops. Article 31.1.2 of the Code is clear about the formation of species-group names from modern personal names: the correct ending for a species named after a group of persons comprised of a man and a woman is "-orum". Hollardops burtandmimiae is changed here into H. burtandmimiorum accordingly.

Chatterton \& Gibb (2010) described Belenopyge bassei as a species of Lobopyge Prribyl \& Erben, 1952. However, the trilobite genus Lobopyge is a junior homonym of the millipede genus Lobopyge Attems, 1951. Özdikmen (2009, p. 158-159) proposed the use of the trilobite genus Belenopyge Pek \& Vaněk, 1991 which was regarded as

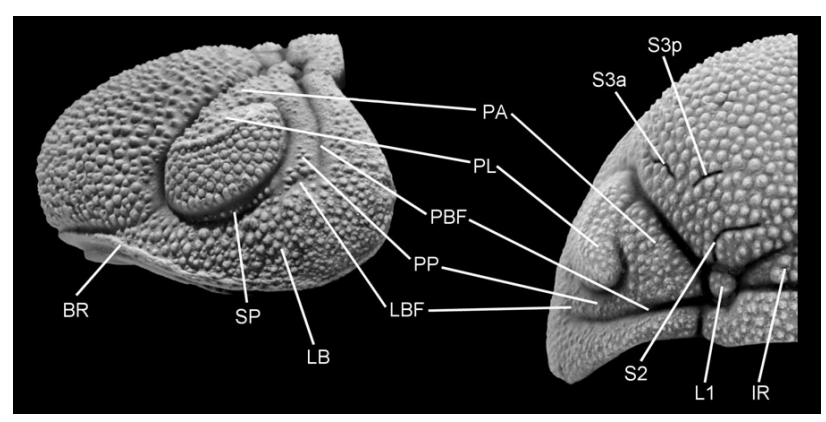

Figure 4. Phacopine cephalic terminology. Abbreviations: BR - border ridge, $\mathrm{SP}$ - subocular pad, $\mathrm{LB}$ - lateral border, $\mathrm{LBF}$ - lateral border furrow, PP - postocular pad, PBF - posterior border furrow, PL - palpebral lobe, PA - palpebral area, S3a - anterior branch of S3 lateral glabellar furrow, S3p - posterior branch of S3 lateral glabellar furrow, S2 - S2 lateral glabellar furrow, L1 - L1 lateral glabellar lobe, IR - intercalating ring.

a junior subjective synonym of Lobopyge subsequent to a cladistic analysis (Ebach \& Ahyong 2001). Özdikmen's (2009) proposal was previously followed by van Viersen \& Prescher (2009), albeit with the caveat that the results of the cladistic analysis were indeed correct, and by Morzadec in Morzadec et al. (2015). We retain Belenopyge but under the same condition as van Viersen \& Prescher (2009). Some workers (e.g., Thomas \& Holloway 1988, Ebach \& Ahyong 2001, Chatterton \& Gibb 2010) have treated Lobopyge as a subgenus of Acanthopyge Hawle \& Corda, 1847. Chatterton \& Gibb (2010) have performed varieties of Ebach \& Ahyong's (2001) analysis and included their new species from Issoumour. None were satisfactory and so they stressed the need for a comprehensive analysis including more African and European species. We agree with their viewpoint. However, because of the conditional content of Belenopyge there is currently no justification for its use as a subgenus of Acanthopyge.

\section{Repository}

The trilobite specimens described in the present paper are housed at the Natuurhistorisch Museum Maastricht (NHMM), Maastricht, the Netherlands.

\section{Systematic palaeontology}

Morphological terminology. - Terminology used in the descriptions of this paper follows Whittington \& Kelly (1997). Phacopine morphological terms were explained by Chlupáč (1977, pp. 10, 11, fig. 1) and several important landmarks are adopted herein (Fig. 4).

Chlupáč (1977) considered the lateral cephalic border to be the vast area between the lateral border furrow and the cephalic margin. Holloway (2013) pointed out that the true 
width of the cephalic border in trilobites is defined by the interior margin of the doublure and that the furrow lying outside the border furrow in some trilobites is the epiborder furrow. The doublure in phacopines is known to be long (sag., exsag.) anteriorly (compare Fig. 5B), but it is rudimentary (tr.) laterally in taxa that we know from ventrally prepared specimens (compare Fig. 5B; Bruton \& Haas 1997, pl. 11, fig. 2a); an epiborder furrow is not developed. We believe that the true lateral border furrow of phacopines coincides with the abaxial limit of the postocular pad. Chlupáč's (1977) viewpoint that the area abaxial of that furrow corresponds to the lateral border is therefore retained. Although the lateral border is particularly wide (tr.) in the taxa described herein, its width is clearly reduced in some other members of the same subfamily (compare Chlupáč 1977, pl. 5, fig. 14; Lespérance \& Sheehan 1987, pl. 3, fig. 2) and there is no reason to doubt that those features are homologous. Thus we believe that Holloway's (2013) definition, which is certainly true for scutelluids and tropidocoryphids, does not apply to phacopine trilobites. It should be noted that the anterior and lateral cephalic margins of some phacopines can be accentuated by the presence of a border ridge. This feature was elaborated on by Struve (1970, 1982); it is here discussed under Adrisiops gen. nov. (see below).

Family Phacopidae Hawle \& Corda, 1847

Subfamily Phacopinae Hawle \& Corda, 1847

\section{Genus Morocops Basse, 2006}

(= Barrandeops McKellar \& Chatterton, 2009)

Type species. - Phacops (Phacops) sparsinodosus struvei Schraut, 2000b from the late Emsian to Eifelian Timrhanrhart Formation (lower Eifelian part) in Morocco, by monotypy.

Diagnosis. - Cephalic sculpture of coarse conical or spiny tubercles in moderate to high density across entire glabella; sculpture slightly reduced on other dorsal cephalic surfaces; doublure sculpture of short, discontinuous terrace lines. Glabella bulbous, with minor anterior overhang; eyes following glabellar contours, with palpebral lobe usually significantly lower than palpebral area. Eye bearing 18-19 vertical rows of lenses, typically with a maximum of 4-6 lenses per row. Interlensar sclera moderately thick ventrally and much thicker dorsally, with some modifications to this general style. Postocular length (exsag.) approaching that of posterior border, leaving a relatively pronounced and expansive postocular pad (often tuberculate) adjacent to variably pronounced subocular pad. L1 lateral lobes large and inflated; most other lobes subdued. L2 and L3 separated by weak $\mathrm{S} 2$ and $\mathrm{S} 3$ which are almost obliterated by sculpture; S1 continuous, but shallowing medially. Thorax width tapering significantly backwards; coarse conical/ domed tubercles present on most dorsal and lateral surfaces of segments. Pygidium with numerous, well-defined axial rings (7-8) and pleural ribs (4-5) and pervasive tuberculate to slightly spiny sculpture.

Notes. - Basse (2006) referred to the type species for a generic diagnosis since he considered Morocops to be monotypic, but this does not cover the species diversity as currently recognised. McKellar \& Chatterton's (2009, p. 44) diagnosis of Barrandeops is adopted and only emended herein to include Morocops spinifer sp. nov.; no emendation was necessary to include $P$. (P.) sparsinodosus struvei.

Other species. - Barrandeops chattertoni Khaldi, Crônier, Hainaut, Abbache \& Ouali Mehadji, 2016 (upper Emsian, Algeria); Barrandeops forteyi McKellar \& Chatterton, 2009, (upper Emsian, Morocco); Phacops granulops Chatterton, Fortey, Brett, Gibb \& McKellar, 2006 (upper Emsian, Morocco); Phacops lebesus Chatterton, Fortey, Brett, Gibb \& McKellar, 2006 (lower Eifelian, Morocco); Barrandeops ovatus McKellar \& Chatterton, 2009 (upper Emsian, Morocco); Phacops (Phacops) saberensis torkozensis Schraut, 2000a (?upper Emsian, Morocco) and Morocops spinifer sp. nov. (upper Emsian, Morocco).

Discussion. - The content of this genus has varied markedly throughout its relatively brief existence to date. Basse (2006) regarded Morocops as a monotypic genus whereas McKellar \& Chatterton (2009) considered it to be a taxon of doubtful generic rank closely related to Geesops Struve, 1972. Later, Basse (2012) enhanced his initial concept in adding Phacops lebesus, a species that had been assigned to Barrandeops by McKellar \& Chatterton (2009). Van Viersen \& Holland (2016) regarded Morocops as a senior subjective synonym of Barrandeops. These contrasting opinions arose because the type species of Morocops, M. struvei, has been subject to different interpretations. Schraut (2000b) described M. struvei as a subspecies of Geesops sparsinodosus (Struve, 1970) while noting what he considered to be minor ontogenetic variations among his type series. These are changes in the divergence of the glabellar axial furrows, the lateral inclination of the eyes and the size and distribution of cephalic sculpture. Basse (2006), having examined Schraut's types, argued that one paratype (Schraut 2000b, fig. 8m-o) is in more than those ways dissimilar from the other types and rejected Schraut's claim that the differences observed should all be attributed to ontogeny. McKellar \& Chatterton (2009) inadvertently took Basse (2006) to have corroborated Schraut's (2000b) ontogenetic suggestion and advanced arguments as to why the differences observed were unlikely to occur within a single species (i.e., in fact, they agreed fully with Basse 2006). McKellar \& Chatterton (2009, p. 21) stated that they 
coded $M$. struvei for cladistic analysis based on, "the large form (the type specimen and paratypes sharing its thick sclera)", although they did not specify these paratypes nor did they provide arguments for their decision. Their cladistic analysis did not reveal a particularly close phylogenetic relationship between Morocops and Barrandeops, but this conclusion cannot be validated because it is not clear which types were used to code $M$. struvei. Van Viersen \& Holland (2016) pointed out that the type series of $M$. struvei encompassed at least two distinct species, whereas only the holotype and a single paratype (Schraut 2000b, fig. 8p, q) were congeneric with species assigned by McKellar \& Chatterton (2009) to their new genus Barrandeops (type species: B. forteyi). Consequently, van Viersen \& Holland (2016) regarded Barrandeops as a junior subjective synonym of Morocops which is the oldest available name. This view is retained by us. Regardless of the identities of the various paratypes, the holotype of $M$. struvei bears all of the diagnostic features of Barrandeops as according to McKellar \& Chatterton's (2009) and is, above all, similar to stratigraphically young species of the group (see below). Furthermore, we disagree with the previous viewpoint of Chatterton et al. (2006) who considered all of the types figured by Schraut (2000b) to be very similar to their new species Phacops smoothops, a species transferred by McKellar \& Chatterton (2009) to their new genus Austerops and later synonymised with Phacops menchikoffi Le Maître, 1952 by Khaldi et al. (2016).

McKellar \& Chatterton (2009) were conservative in only assigning to Barrandeops species described by themselves and by Chatterton et al. (2006) from Morocco. Potential other members of Morocops are likely to be found primarily in upper Emsian strata in Gondwana and peri-Gondwanan terranes (see below). The stratigraphically earliest confirmed species of Morocops (i.e., M. forteyi, M. spinifer sp. nov. and $M$. torkozensis) occur in the basal upper Emsian of southern Morocco. These species share a smoothly and widely rounded cephalon, a broad glabella with widely rounded anterior margin, weakly to moderately weakly inclined (tr.) low visual surfaces with comparatively few lenses per dorsoventral file (the number of files seems to be stable at 18-19, however). In contrast, stratigraphically younger species (M. ovatus, M. lebesus, but also the type species $M$. struvei) demonstrate a progressively Geesops-like morphology: the cephalic contour (dorsal view) becomes increasingly parabolic to subtriangular, the subocular pad is weak and the lateral border furrow faint, the postocular pad decreases as the eye migrates posteriorly, the lateral border transforms into a large homogeneous plain of angular outline, the glabella is narrower, the palpebral lobe and area are of equal height (M. lebesus only), pits are present on the palpebral lobe and lateral cephalic border (M. struvei only) and the maximum number of lenses per dorsoventral file increases.
The stratigraphically youngest species of Morocops, M. lebesus, from the basal Eifelian of Morocco, is exceedingly similar to one of the stratigraphically oldest members of Geesops, G. sparsinodosus gallicus Struve, 1982 from coeval strata in the French Ardennes. Schraut (2000b, fig. 8d-f) recorded an exceptionally well-preserved, enrolled specimen of that subspecies that differs merely from the types of M. lebesus figured by Chatterton et al. (2006, pl. 3, figs 1-9) in having larger tubercles centrally on the glabella, fewer tubercles on the lateral border below the eye, and a narrower (exsag.) posterior cephalic border. Some workers might dismiss the similarities as mere convergence. However, we argue that the gradual morphological transition between Morocops and Geesops, along with the slight overlap of their stratigraphic ranges, are tell-tale signs of a grade taxon. Further investigations will be needed to assess the phylogenetic relationships of members of these genera. If such a work is to corroborate a close affinity of M. lebesus and G. sparsinodosus gallicus then Morocops, as presently defined, is almost certainly paraphyletic. It should be borne in mind that the type species of Barrandeops is a basal member of the group, different from stratigraphically younger species (including $M$. struvei) that show a Geesops-like morphology. Barrandeops might be salvaged subsequent to future cladistic analysis. However, we underline the primary need for more reliable raw data, starting with timely revisions of candidate species of Morocops recorded in the literature. Until then Morocops remains the oldest available name.

Occurrence. - Upper Emsian to lower Eifelian of Morocco and upper Emsian of Algeria.

\section{Morocops torkozensis (Schraut, 2000a)}

Figures 5A-E, J, K, 7M

2000a Phacops (Phacops) saberensis torkozensis n. ssp.; Schraut, pp. 374, 375, text-fig. 8, pl. 3, figs 3-6.

2004a Phacops saberensis torkozensis. - Becker et al., p. 86.

2004 Phacops (Phacops) saberensis torkozensis. - Jansen et al., p. 82.

2010 Phacops saberensis torkozensis. - Bonino \& Kier, pl. 172, fig. c.

2012 Phacops (Phacops) saberensis torkozensis. - Basse, p. 155 [listed as a species of Barrandeops].

? 2012 Phacops saberensis. - Brett et al., p. 31, fig. 6d, e, $\mathrm{g}-\mathrm{i}$.

2016 Phacops (Phacops) saberensis torkozensis. Khaldi, Crônier, Hainaut, Abbache \& Ouali Mehadji, p. 360.

Material. - One complete, enrolled specimen (NHMM 2016 002) from the upper part of the Hollardops Limestone 
Member, Khebchia Formation, Tadachacht locality, Morocco.

Description. - Cephalon widely rounded, moderately weakly vaulted (tr.). Occipital ring as high as glabella anterior to S0, covered with densely spaced tubercles. Axial furrows deep posterior to $\gamma$; diverging at around $80^{\circ}$. Intercalating ring with crowded tubercles that are similar in shape and size to adjacent tubercles anterior to S0. L1 lateral lobes moderately strongly inflated, of rounded outline, bearing several tubercles. Glabella smoothly rounded (sag.), with slight to moderate anterior overhang. S2 lateral glabellar furrows firmly incised; anterior and posterior branches of S3 moderately weakly incised. Broad palpebral area, much higher than palpebral lobe, covered with close-set tubercles similar to those on occipital ring. Palpebral furrow firmly impressed. Palpebral lobe downwardly sloping (tr.) abaxially, bearing numerous tubercles. Visual surface comprised of 18 dorsoventral files with maximally 4 lenses per file; sclera thin above and below lenses in the ventral half of the visual surface, and thick in the dorsal half. Subocular pad rudimentary but accentuated by a row of tubercles. Postocular pad moderately weakly inflated, accentuated abaxially by tubercles. Lateral and posterior borders bearing numerous tubercles that are elongated ridges (exsag.) near lateral border. Genal angle subrounded. Lateral border with weak border ridge, bearing densely spaced granules that merge to form short, border parallel terrace lines.

Thorax consisting of 11 segments with distinct lateral lobes. Axial rings bear close-set tubercles similar to those on occipital ring. Pleural furrow broad (exsag.) and deep proximally, absent distally. Pleurae bearing numerous small tubercles everywhere.

Pygidium comprising 8 axial rings and 6 pairs of pleurae. Axis weakly vaulted (tr.). Anterior four to five rings somewhat $\mathrm{W}$-shaped. Sculpture of numerous, ubiquitous tubercles on axis and pleural fields.

Remarks. - The stratigraphic and geographical origins of the type series are ambiguous. In the same paper Schraut (2000a, pp. 368, 374, fig. 6) described the type horizon as Rich 3 (= El Ansar Formation, upper Emsian), as an interval between beds 21 and 22, and as the lower part of unit 22 in the lowermost part of the Khebchia Formation. Schraut (2000a) furthermore indicated that $P$. (P.) saberensis torkozensis occurred in the Khebchia Formation (Rich 4) at a section called Timziline (p. 366) and in the basal part of the Merzâ-Akhsaï Formation (Pragian part) at a section called Tadoucht II (p. 365). This last occurrence, however, is rather stratigraphically low for any species of Morocops and presumably an error. The type locality of M. torkozensis was defined by Schraut (2000a) as section Torkoz IIa (pp. 366, 374), but this species is not among trilobites listed in his description of this locality nor does it occur there according to his lists of species per locality (pp. 366, 369, table 1). Schraut (2000a) apparently did not collect the type specimens himself; he referred to an exchange of letters as the source of his stratigraphic and geographical information (pp. 363, 366). Becker et al. (2004a) discussed the Torkoz IIa section and assigned the lower part of unit 22 to the Oui-n-Mesdoûr Formation which underlies the Khebchia Formation, while mentioning abundant $P$. (P.) saberensis torkozensis and Hollardops mesocristatus in the overlying Hollardops Limestone Member. It leads us to the most parsimonious explanation that the types came from the upper Emsian at Torkoz IIa and more specifically, probably from the basal part of the Khebchia Formation.

Schraut's (2000a) types are deformed and partially exfoliated specimens. We record a well-preserved specimen from the basal part of the Khebchia Formation at the nearby locality of Tadachacht, which is, as far as could be compared, indistinguishable from the types. Schraut originally designated $M$. torkozensis a subspecies of Phacops (Phacops) saberensis Morzadec, 1969. Morzadec's material is from Spain and must be re-examined in order to corroborate a close affinity of these taxa. Hence, we treat M. torkozensis as a distinct species here.

Schraut (2000a) recorded a second species, Phacops (Phacops) vogeli Schraut, 2000a, from "grey calcareous limestones" at Torkoz IIa. Basse (2006, pl. 29, fig. 276) refigured the holotype cephalon after much-needed further preparation which revealed many new details of its morphology. This species is very different from $M$. torkozensis and congeners in having comparatively few, large tubercles and large eyes that reach backwards as far as the border furrow. The visual surface is comprised of just 14-15 dorsoventral files. Following Basse (2006), its generic assignment is uncertain.

\section{Morocops spinifer sp. nov.} Figure 6A-M

? 2004b Phacops saberensis torkozensis. - Becker et al., p. 92.

Holotype. - The complete, enrolled specimen in Fig. 6A-D, G, J, L, M, NHMM 2016004.

Paratype. - One enrolled specimen, lacking the pygidium, NHMM 2016005.

Etymology. - Derived from the Latin for 'bearing spines'. Gender masculinum.

Type locality. - Bou Tserfine locality.

Type horizon. - Basal part of the Hollardops Limestone Member, Khebchia Formation. 

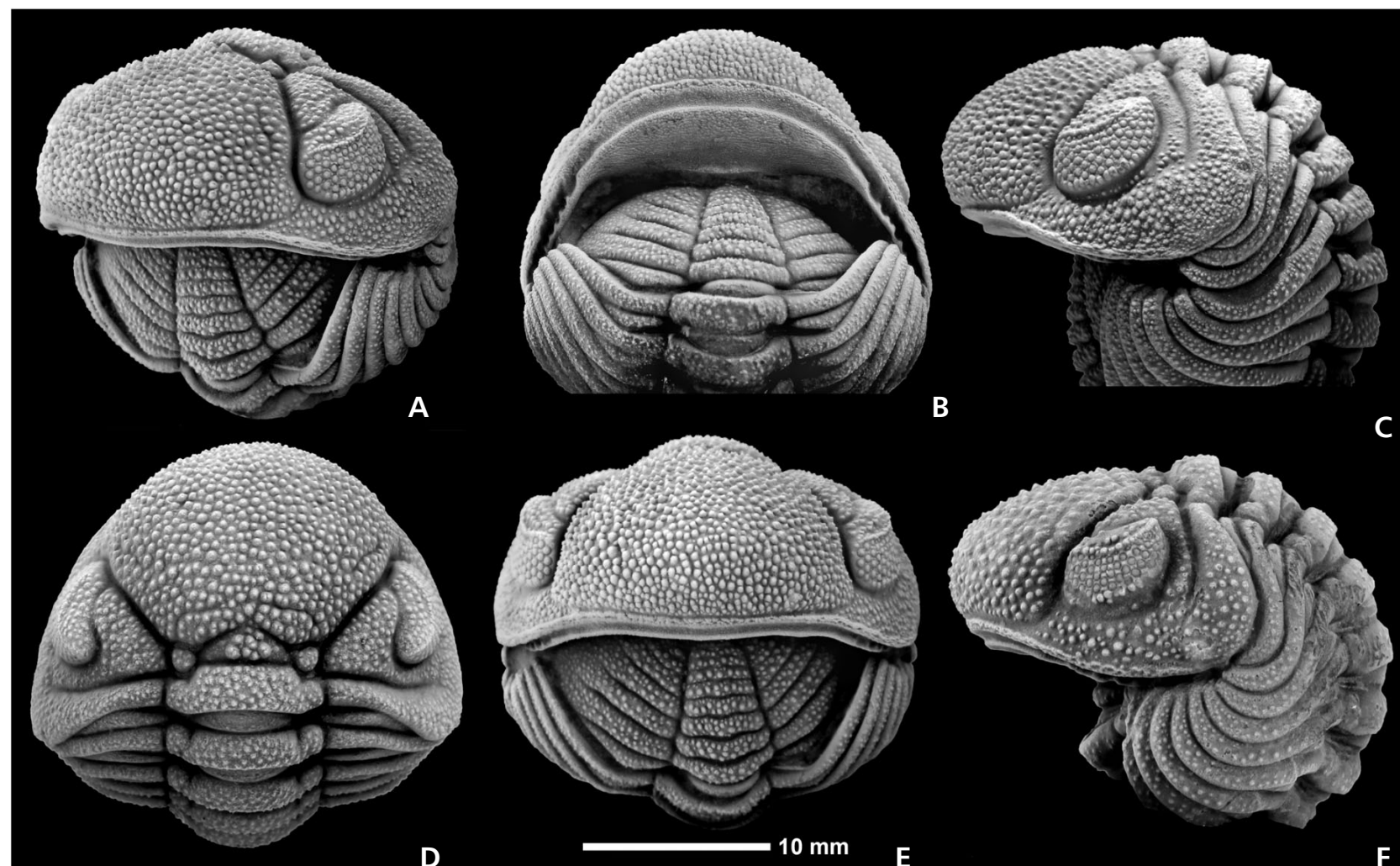

C

D
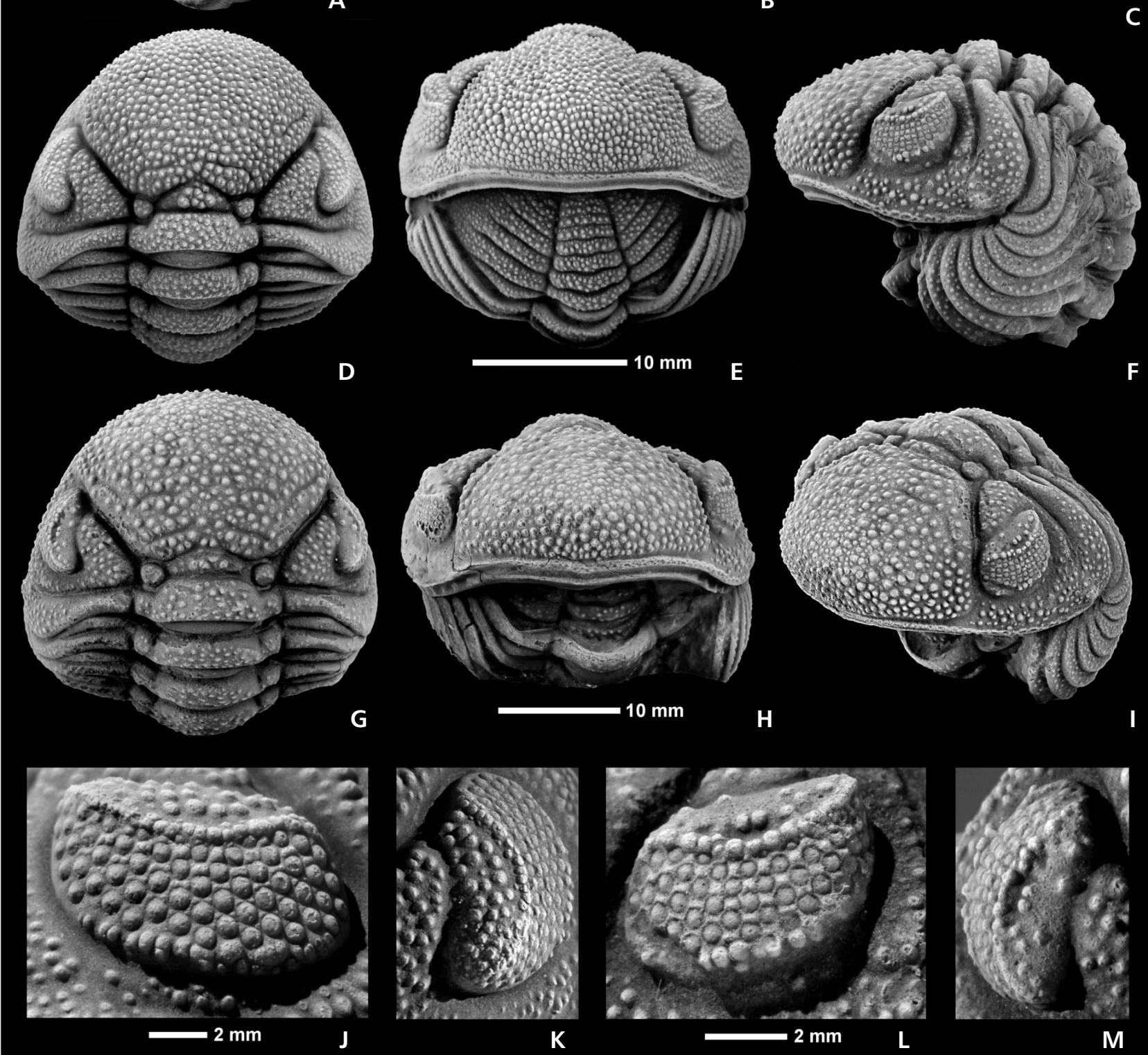

Figure 5. A-E, J, K-Morocops torkozensis (Schraut, 2000a), enrolled specimen, NHMM 2016 002, upper part of the Hollardops Limestone Member, Khebchia Formation (upper Emsian), Tadachacht locality, Morocco; A - anterolateral view of cephalon, B - ventral view of cephalon, C - lateral view, $\mathrm{D}$ - dorsal view of cephalon, $\mathrm{E}$ - anterior view of cephalon, J - right eye, lateral view $\mathrm{K}$ - right eye, dorsal view. $\bullet \mathrm{F}-\mathrm{I}, \mathrm{L}, \mathrm{M}-$ Morocops forteyi (McKellar \& Chatterton, 2009), enrolled specimen, NHMM 2016 003, presumably 'Psychopyge couche', at the locality Bou Dîb of McKellar \& Chatterton (2009), upper Emsian; F - lateral view, G - dorsal view of cephalon, $\mathrm{H}$ - anterior view of cephalon, I - oblique anterolateral view, L - left eye, lateral view, $\mathrm{M}$ - left eye, dorsal view. 
Diagnosis. - Low eyes; visual surface is distinctly inclined (tr.) and comprised of 18 dorsoventral files with maximally 3-4 small lenses per file; sclera is thin throughout. Cephalic sculpture comprised of conical to somewhat spiny tubercles; these are moderately high centrally on the glabella and increasingly spiny frontally and laterally on cephalon. Upper and lower margins of eye each bearing a row of spiny tubercles. Pygidium covered with close-set, conical tubercles that are larger on pleurae than on axis.

Description. - Cephalon widely rounded, moderately weakly vaulted (tr.). Occipital ring as high as glabella anterior to S0, covered with tubercles. Axial furrows deep posterior to $\gamma$; diverging at around $75-80^{\circ}$. Intercalating ring bearing several tubercles that are similar in shape and size to adjacent tubercles anterior to S0. L1 lateral lobes moderately strongly inflated, of rounded outline, bearing several tubercles. Glabella smoothly rounded (sag.), with slight to moderate anterior overhang. S2 lateral glabellar furrows firmly incised; anterior and posterior branches of S3 moderately weakly incised. Broad palpebral area, much higher than palpebral lobe, covered with close-set tubercles similar to those on occipital ring. Palpebral furrow moderately weakly impressed but developed throughout. Palpebral lobe smooth and weakly inclined (tr.) adaxially, downwardly sloping (tr.) abaxially, bearing a row of several large spiny tubercles parallel to margin. Subocular pad rudimentary but accentuated by a row of spiny tubercles. Postocular pad moderately weakly inflated, accentuated abaxially by spiny tubercles. Lateral border and abaxial half of posterior border bearing large, spiny tubercles together forming two border parallel rows anterior of $\delta$. Genal angle subrounded, with distinct node. Lateral border with weak border ridge, bearing densely spaced granules that merge to form short, border parallel terrace lines.

Thorax consisting of 11 segments with distinct lateral lobes on axial rings. Axial rings bear close-set tubercles slightly smaller than, but otherwise similar to those on occipital ring. Pleural furrow broad (exsag.) and deep proximally, absent distally. Pleurae bearing a row of tubercles on horizontal proximal part; abaxial to this, where pleural furrow is undeveloped, sculpture consisting of a row of small tubercles along anterior margin and few, randomly scattered, moderately small tubercles elsewhere.

Pygidium comprising 8 axial rings and 5 pairs of pleural ribs. Axis weakly vaulted (tr.). Anterior three rings in- dented posteromedially but without well-developed interannular rings. Two terrace ridges visible dorsally along lateral to posterior pygidial margin. Sculpture of numerous, ubiquitous spiny tubercles on axis and pleural fields; pygidial border bearing close-set, coarse granules.

Remarks. - The differences between M. torkozensis, $M$. forteyi and $M$. spinifer sp. nov. are subtle and most clearly expressed in the eyes and dorsal sculpture. The new species is similar to the stratigraphically slightly younger M. forteyi. McKellar \& Chatterton (2009) included specimens from several upper Emsian strata at localities in Morocco in $M$. forteyi, which show some morphological variations and may not all be conspecific. Their paratypes from the 'Psychopyge couche' at Bou Dîb (not the type locality) (compare Fig. 5F-I, L, M) bear the closest resemblance to our types; these differ principally from $M$. spinifer $\mathrm{sp}$. nov. in having densely spaced tubercles instead of spines all over the cephalon. Additionally, the genal angle is more smoothly rounded, the visual surface is much steeper (tr.) and larger (due to the less tightly packed lenses), and the pygidium bears comparatively small tubercles. According to McKellar \& Chatterton (2009) the sclera of M. forteyi are extremely pronounced, often bearing tubercles above and below lenses, forming a cruciform arrangement of the lenses (compare Fig. 5L, M). Of note is that M. torkozensis shows this same feature in the dorsal half of the eye (compare Fig. 5J, K).

The numerous spiny tubercles anteriorly and laterally on the cephalon of $M$. spinifer sp. nov. are a unique feature among members of the Phacopinae. Spiny phacopines have been recorded from the Pragian in the USA (Haas 1969) and Australia (Wright \& Haas 1990), as well as from the Eifelian in Morocco (Struve 1995). All of these have comparatively few, long spines concentrated on specific parts of the cephalon, thorax and pygidium. The function of these spines arguably is a defensive one. However, the possibility of their use as camouflage, as for example suggested in some homalonotines (see, e.g., Müller 2005), cannot be excluded. The spines of $M$. spinifer sp. nov. are numerous and appear to have replaced the conventional tubercles of other species (e.g., M. forteyi). This suggests that they took over their specific function, perhaps as an environmental adaptation. We postulate that these adaptations were used to facilitate digging. Many phacopines are considered to have been detritivores with a semi-infaunal or infaunal lifestyle (Bruton \& Haas 1997, McKellar \&

Figure 6. A-M - Morocops spinifer sp. nov., holotype enrolled specimen, NHMM 2016 004, basal part of Hollardops Limestone Member, Khebchia Formation (upper Emsian), Bou Tserfine locality, Morocco; A - dorsal view of cephalon, B - lateral view, C-anterior view, D - dorsal view of pygidium, $\mathrm{G}$ - right part of cephalon, oblique posterolateral view, $\mathrm{J}$ - right eye, lateral view, L - cephalon, oblique anterolateral view, $\mathrm{M}$ - right part of cephalon, oblique lateral view. $・$ E, F, H, I, K - Morocops spinifer sp. nov., paratype, NHMM 2016 005, from 1 metre above level of holotype; E - enrolled specimen, anterior view, F - dorsal view of cephalon, $\mathrm{H}$ - lateral view, I - anterolateral view, $\mathrm{K}$ - cephalon, oblique ventral view. 


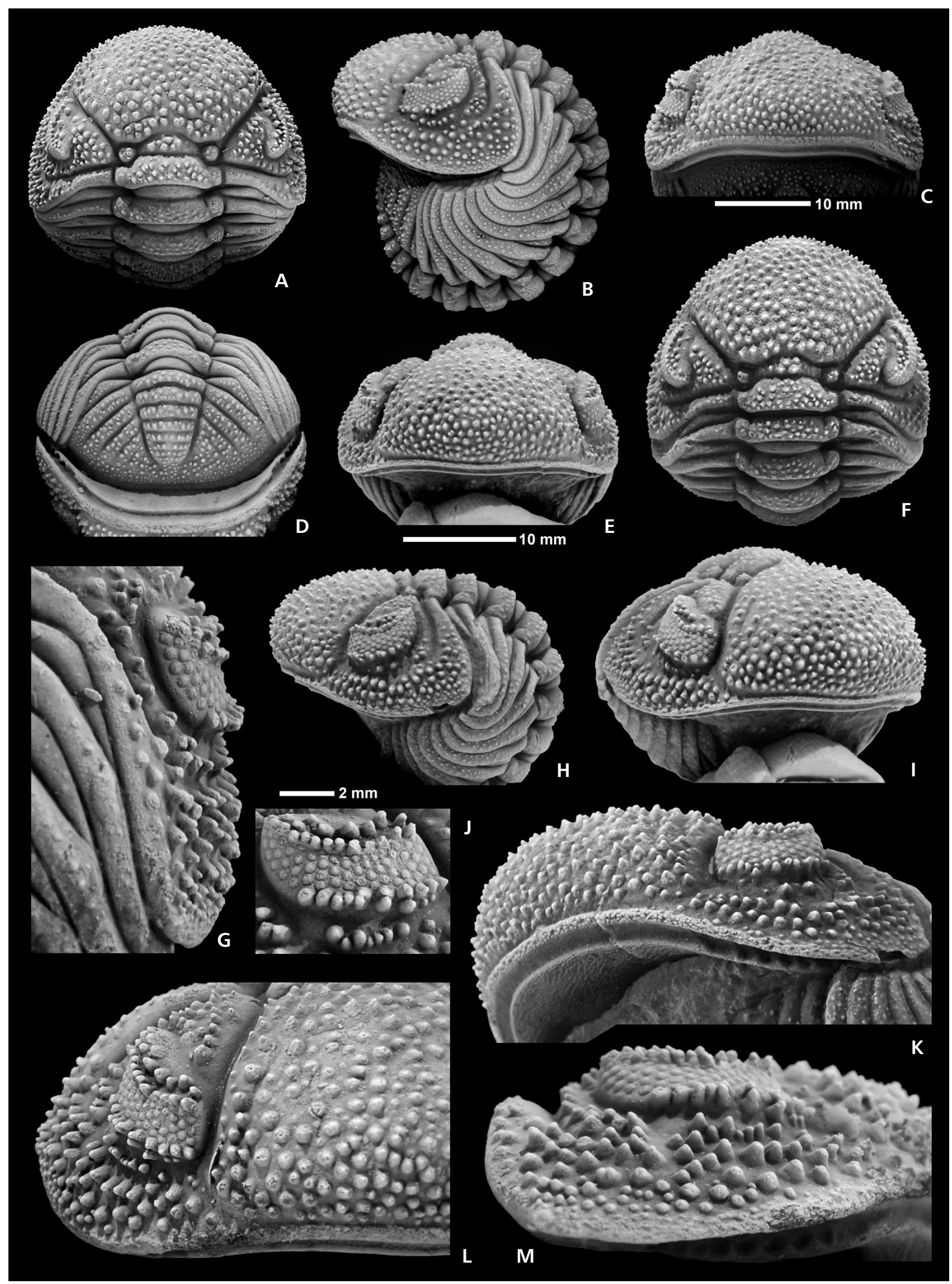


Chatterton 2009). Most species of Morocops inhabited muds (McKellar \& Chatterton 2009) but to date M. spinifer sp. nov. is known exclusively from biodetritic marls. The behaviour of detritus-rich sediments is principally different from that of muds and consequently they require different tools to burrow in. Pure muds behave like elastic solids; they are bonded by cohesion and deform under stress until eventually failing. Dorgan et al. (2005) demonstrated how some annelid worms move through gelatine, which behaves similarly to muds, by means of crack propagation. The sediments that yielded our trilobite specimens contained myriads of tiny cone-shaped tentaculites of irregular orientation. These tentaculites would have acted as interwoven masses stacked by gravity making it difficult for the trilobites to burrow. We hypothesise that the spines anteriorly and laterally on the cephalon of $M$. spinifer sp. nov. were used to drag and displace the coarse biodetritic content of the sediments.

\section{Genus Adrisiops nov.}

Type species. - Adrisiops weugi gen. et sp. nov. from the late Emsian to Eifelian El Otfal Formation (upper Emsian part) in Morocco.

Etymology. - Combination of 'adrisio' (Latin: the action of smiling) + 'ops' (Greek: eye), a common suffix of phacopine genera, in reference to the name "smiley Phacops" that has been applied informally to members of the new genus. Gender masculinum.

Diagnosis. - Strongly vaulted (tr.) phacopine. Intercalating ring rudimentary or absent. Glabella short, strongly vaulted (tr., sag.), steep and with slight overhang anteriorly, of angular outline (lateral view), bearing conical tubercles centrally, transversely expanded tubercles frontally and much reduced or no sculpture near anterior border. Palpebral area lower than palpebral lobe. Palpebral lobe bearing few small tubercles; otherwise smooth. Axial furrow narrow but deep anterior of $\gamma$. Small or rudimentary, subtriangular postocular pad, only ever developed abaxially. Eye positioned comparatively far ventrally, tilted towards front, comprised of 19 dorsoventral files each with up to 6 tightly packed lenses separated by thin, weakly tuberculated sclera. Lateral border demarcated by a sharp edge, which remains at a moderately large to large distance from the eye. Border furrow firmly impressed in front of glabella, less so medially. Anterior border dorsally flattened, lacking sculpture, ventrally deflected medially, and bearing a keel-like border ridge.

Other species. - Phacops boudjemaai Khaldi, Crônier, Hainaut, Abbache \& Ouali Mehadji, 2016 (upper Emsian, Algeria) and Geesops fabrei Khaldi, Crônier, Hainaut, Abbache \& Ouali Mehadji, 2016 (upper Emsian, Algeria). Although, at present, only three species are assigned to this genus, we are aware of occurrences of at least three others in upper Emsian and Eifelian localities in Morocco. Unfortunately, none of these were available for deposition in an institutional collection at the time of writing.

Remarks. - Adrisiops gen. nov. is erected for a group of species that share a unique cephalic morphology among phacopines. We envisage that the inflated glabella housed a digestive system capable of processing large food particles. The dorsally arched pygidial border of $A$. weugi sp. nov. mirrors the ventrally deflected anterior cephalic border (Fig. 7F, H) so that both parts fitted seamlessly during enrolment.

Khaldi et al. (2016) based their generic assignment of Geesops fabrei exclusively on glabellar tuberculation and the pits on the genal angle, which they considered to be similar to those in Geesops schlotheimi (Bronn, 1825), the type species of Geesops (Fig. 7A-C, L). There are several problems with the definition of Geesops sensu Khaldi et al. (2016). Firstly, it was claimed that Geesops was erected by Struve (1982) - the correct year is 1972 - for phacopids with a marginulate [sic!] cephalic border closely related to Phacops. Actually, Struve (1982) believed that the phylogenetic separation of "marginulaten" Phacopinae (a term introduced by Struve to refer to phacopines with a rope-like or keel-like cephalic border ridge) and "nicht-marginulaten" Phacopinae (phacopines without a border ridge, i.e., with a smooth cephalic border) already occurred in the Silurian or even in the Ordovician. Phacops has a smooth cephalic border and thus Struve (1982) argued that the presence of a cephalic border ridge in Struve's (1972, 1976) previously erected subgenera of Phacops justified their elevation to generic rank. Geesops was one of these subgenera. Secondly, Khaldi et al. (2016) included

Figure 7. A-C, L - Geesops schlotheimi (Bronn, 1825), cephalon, NHMM 2016 006, "Gees trilobite beds" (sensu van Viersen et al. 2009), Gees Subformation, Ahrdorf Formation (middle Eifelian), Trilobitenfelder locality near Gees/Gerolstein, Germany [= putative type locality and horizon]; A - cephalon, dorsal view, B - lateral view, $\mathrm{C}$ - anterior view, $\mathrm{L}-$ left eye, anterolateral view. $\bullet \mathrm{D}-\mathrm{K}$-Adrisiops weugi gen. et sp. nov., holotype complete specimen, NHMM 2016 007, Issoumour locality, Morocco, upper Emsian; D - dorsal view, E - lateral view, F - anterior view, G - oblique anterolateral view, $\mathrm{H}$ - posterior view, I - lateral extremity of second right thoracic pleural segment, lateral view, J - left eye, anterolateral view, K - left eye, dorsal view. Morocops torkozensis (Schraut, 2000a), enrolled specimen, NHMM 2016 002; upper part of the Hollardops Limestone Member, Khebchia Formation (upper Emsian), Tadachacht locality, Morocco; $\bullet \mathrm{M}$ - right lateral border, lateral view. 


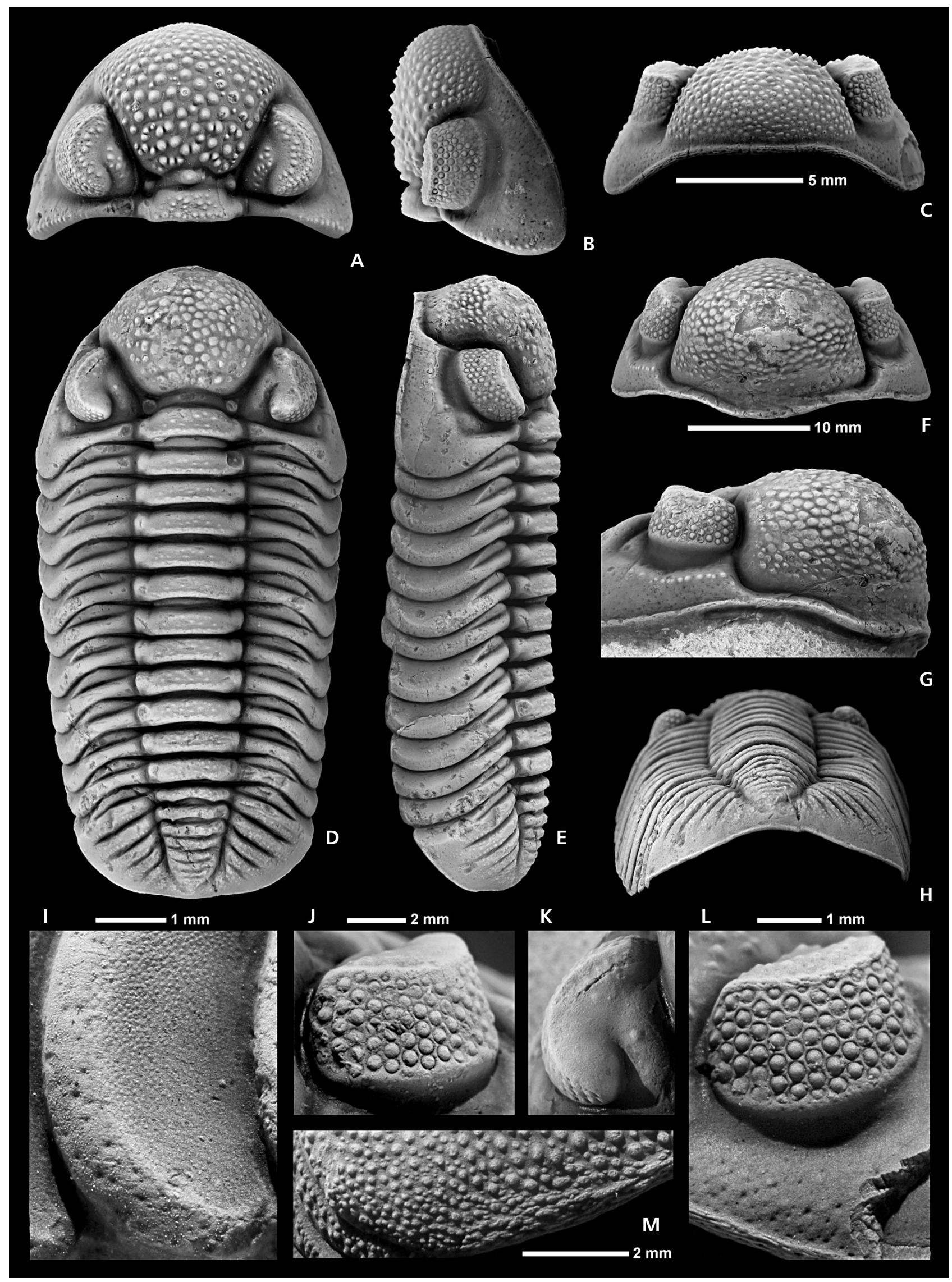


Phacops (Phacops) sparsinodosus struvei, the type species of Morocops, in Geesops, without explanation. This action would irrefutably lead to the synonymy of Morocops with Geesops, which was not addressed by Khaldi et al. (2016), nor is it supported by the present study (see above). Thirdly, all of the new species of Geesops described by Basse (1998, 2006) were omitted. Lastly, Khaldi et al. (2016) included Phacops (Phacops) schlotheimi skalensis Kielan, 1954 from the Givetian in Poland. This species is not a member of Geesops; it was assigned to Nyterops Struve, 1972 by Struve (1972). No subsequent worker has ever questioned this assignment.

Geesops is different from Adrisiops gen. nov. in having a lower (sag.) cephalic outline (in the new genus the outline of the anterior to lateral border is subsemicircular but in dorsal view this feature is concealed by the anteriorly protruding glabella which overhangs the border). Further differences include the well-developed intercalating ring, numerous tubercles on palpebral lobe and area, and equal height of palpebral lobe and area. The glabella is comparatively weakly inflated (sag., tr.) and longer (length/width ratio, excluding occipital ring, is 0.85 in G. schlotheimi vs 0.75 in $A$. weugi sp. nov.). The eyes and visual surface are larger, with considerably thickened sclera dorsally. The posterior border furrow is shallower and the postocular pad is rudimentary or absent. A single row of tubercles is present on the posterior border between the eye and the genal angle. Lastly, the anterior cephalic border is dorsally arched, short (sag., exsag.), with a rope-like anterior cephalic border ridge (even medially).

Phacops differs from Adrisiops gen. nov. in having a well-developed intercalating ring, a comparatively broad, weakly inflated glabella (sag., tr.) with bladder-like tubercles, a visual field comprised of a maximum of 16 dorsoventral files, thick sclera lacking tubercles, and a slightly dorsally arched (anterior view) short (sag.) smooth anterior cephalic border. Basse (2006) regarded Phacops and Cultrops Struve, 1995 (preoccupied; replaced by Struvephacops Ghobadi Pour, 2015) as synonyms because the latter differed merely in having a rudimentary border ridge (Struve 1995). Thus, it appears that Struve's designation of Cultrops as a new subgenus of Phacops was actually in conflict with his earlier hypothesis of a deeply rooted separation of Phacops and "marginulaten" Phacopinae. The presence of a partial cephalic border ridge in species formerly included in Struvephacops suggests that Phacops probably descended from an earlier Emsian ancestor with a border ridge.

Morocops is easily differentiated from Adrisiops gen. nov. by its rich dorsal sculpture comprising numerous, ubiquitous tubercles. The intercalating ring is well developed; the palpepral area is usually wider and distinctly higher than the palpebral lobe. The glabella is comparatively weakly inflated (sag., tr.), demarcated anterior to $\gamma$ by a shallow axial furrow. The lateral cephalic border is weakly adaxially demarcated. Lastly, the anterior cephalic border is weakly dorsally arched (anterior view) and demarcated by a faint anterior border furrow.

Occurrence. - Upper Emsian to Eifelian of Morocco and upper Emsian of Algeria.

\section{Adrisiops weugi gen. et sp. nov. Figure 7D-K}

Holotype. - The complete specimen in Fig. 7D-K, NHMM 2016007.

Etymology. - Named after Andries Weug, who was among the first persons to point out the type locality. Gender masculinum.

Type locality. - Issoumour locality.

Type horizon. - 'Smiley Phacops couche', in all probability basal part of El Otfal Formation, upper Emsian.

Diagnosis. - Moderately well-developed, right-angled triangular postocular pad. Glabella very strongly vaulted (sag., tr.), bearing close-set, conical tubercles centrally and thick, transversely elongated tubercles frontally. Steep (tr.), strongly inflated lateral border. Palpebral area bearing a single tubercle opposite $\delta$. Large distance between lateral border and eye. Broad, widely rounded pygidium with strongly dorsally arched posterior border.

Description. - Cephalon of high parabolic outline. Low occipital ring, slightly shorter sagittally than exsagittally. Axial furrows divergent at around $65-70^{\circ}$. L1 lateral lobes round, not entirely preserved in the holotype but likely to have been moderately strongly inflated. Intercalating ring rudimentary to weakly inflated. Glabella short, angular posteriorly, subsemicircular anteriorly with steep, slightly overhanging front. Palpebral lobe smooth, a few weak tubercles anteriorly excepted. Anteriorly downwardly tilted eye comprised of 19 dorsoventral files with maximally 6 lenses per file; thin sclera horizontally between lenses, rudimentary vertically between lenses. Sculpture: few weak tubercles on L1 lateral lobes; large, conical tubercles centrally on glabella (most are poorly preserved in the holotype), which are transversely expanded on frontal part; row of tubercles on abaxial edge of lateral border; remainder of dorsal side of cephalon devoid of any sculptural elements.

Eleven thoracic segments. Axial lobe about as wide as pleural lobes. Axis widest across fourth ring (width equalling $104.85 \%$ of first ring), narrowest across last ring (width equalling $84.47 \%$ of first ring). Sculpture: axial rings with few, weak tubercles similar to those on L1 lateral lobes; 
pleurae devoid of elements but posterior pleural bands bearing abundant pits.

Pygidium comprising 8 axial rings and 5 pairs of pleural ribs. Axis weakly vaulted (tr.). Anterior two rings indented posteromedially, with well-developed interannular rings. Rope-like border ridge along lateral to posterior pygidial margin. Sculpture: few, weak tubercles; densely spaced granules on pleurae; pygidial border smooth or with fine granules.

Remarks. - Adrisiops fabrei (Khaldi et al., 2016) has smaller L1 lateral lobes, a wider (tr.) palpebral area, a smaller postocular pad, a narrower gap between lateral border and eye, less inflated lateral border and glabella, more tubercles on the lateral border surrounding the eye, and a less ventrally deflected anterior border. Adrisiops boudjemaai (Khaldi et al., 2016) differs in having a wider palpebral area with more tubercles, smaller, more widely spaced tubercles centrally on glabella, firmly incised S2 lateral glabellar furrows, shorter, taller eyes, and a less ventrally deflected anterior border.

\section{Palaeobiogeographical and evolutionary implications}

All currently recognised species of Morocops come from upper Emsian to lower Eifelian deposits on the northern Gondwanan shelf (i.e., the southern margin of the Rheic Ocean; Fig. 8). The stratigraphically earliest confirmed members (M. spinifer sp. nov., M. torkozensis) occur in the basal upper Emsian in southern Morocco, close to the main deepening of the Daleje Event (Becker et al. 2004b). Potential other species of Morocops have been described from upper Emsian strata in Morocco (e.g., Alberti 1983, pl. 2, fig. 12; Klug et al. 2009, p. 119, fig. 2), the Cantabrian Mountains (e.g., Smeenk 1983, pl. 30, figs 1-6), Brittany (e.g., Morzadec 1969, pl. 26, figs 7, 8), the Barrandian (e.g., Chlupáč 1977, pl. 10, figs 1-18) and northwest Turkey (e.g., Haas 1968, pl. 30, figs 6, 7) (Fig. 8). Haas's trilobites from the Gebze Formation in Turkey have been widely assumed to be Eifelian but were revised as early late Emsian by van Viersen \& Holland (2016). It is striking that all of these potential species of Morocops are either Gondwanan or peri-Gondwanan. If their affinity with Morocops is correct then the palaeogeographical distribution of the genus in the upper Emsian could be similar to that of other "Bohemian" trilobites that benefitted from the Daleje Event (Chlupáč \& Kukal 1986).

There are currently no species of Morocops known with certainty from Laurussia (i.e., the northern margin of the Rheic Ocean). The majority of upper Emsian occurrences of Phacopinae in the Ardenno-Rhenish Mountains have been referred either to Arduennops Struve, 1972, Pedinopariops Struve, 1972 or Phacops (see Basse 2006).

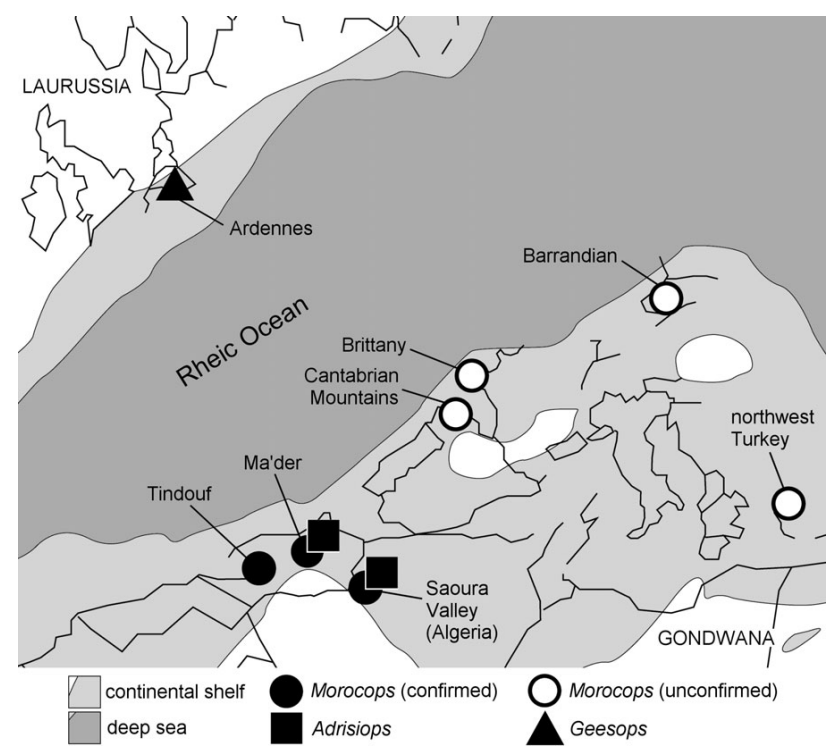

Figure 8. Map of western Europe and northwest Africa showing the palaeogeographical distribution of Adrisiops gen. nov., Geesops and Morocops during the late Emsian to earliest Eifelian (map modified and simplified after Scotese 2014).

However, as discussed above, one of the oldest members of Geesops, G. sparsinodosus gallicus from the basal Eifelian in the French Ardennes, is exceedingly similar to the stratigraphically youngest species of Morocops from coeval strata in Morocco. The French subspecies is part of a mixed "Rhenish-Bohemian" outer shelf biota that occurs at the famous "Mur des douaniers" locality near the town of Vireux-Molhain (van Viersen 2006, 2008; Crônier \& van Viersen 2008). The "Mur des douaniers" assemblage comprises some of the stratigraphically earliest occurrences of "Bohemian" trilobites on the southern Laurussian shelf. These include aulacopleurids (Cyphaspis), proetids (Diademaproetus, Gerastos), lichids (Ceratarges), odontopleurids (Kettneraspis, Koneprusia) and scutelluids (Scabriscutellum), all of which were already present in Gondwana (e.g., Morocco; see Chatterton et al. 2006) and peri-Gondwana (e.g., Brittany; see Morzadec 1983) during the Early Devonian. The occurrence of species of Septimopeltis at Vireux-Molhain is particularly significant since it is the sole record of this genus from the Ardenno-Rhenish Massif left of the river Rhine to date (van Viersen 2006). Unfortunately, little is known about the biostratigraphy and palaeoecology of the trilobites from the "Mur des douaniers" locality, which was declared a natural reserve by the French authorities in 1991. New excavations for scientific studies there are not allowed (C. Crônier, pers. comm. to AvV, June 2008). Nonetheless, the incursion of "Bohemian" trilobites in the French Ardennes in the basal Eifelian indicates that exchange of trilobite faunas between the southern and northern margins of the Rheic Ocean was unhindered at this time. In fact, it 
has been suggested in other studies (e.g., Schraut \& Feist 2004; van Viersen \& Prescher 2009; van Viersen 2013, $2015)$ that the incursion of "Bohemian" trilobites in Laurussia already started in the Emsian or even the Pragian. We regard this as evidence to support the putative close relationship between species of Morocops and Geesops despite the fact that they were separated by an ocean.

Presently assigned species of Adrisiops gen. nov. were only recently discovered and several more species have already been reported by local workers. Although the rapid pace of these discoveries precludes a comprehensive discussion on biostratigraphy and palaeogeography, the new genus appears to be restricted to upper Emsian and Eifelian strata in Morocco and upper Emsian strata in Algeria. Some species of Adrisiops have been earlier referred to Phacops and Geesops but we reject such close affinities between members of these genera. Geesops appears closely related to Morocops, a genus with earliest late Emsian or even early Emsian roots. The stratigraphically oldest species of Phacops come from the upper Emsian in the Rhenish Mountains (see Basse 2006). As pointed out above, these are distinct from Adrisiops gen. nov.

\section{Conclusions}

The classification of Phacops and similar genera in the Lower and Middle Devonian continues to be a topic of debate despite important advances made in recent studies. This is largely due to the difficult appraisal of phylogenetically informative characters and the deficient data set. More data on species involved could help to resolve this issue. The species recorded herein are attributed to Morocops, Adrisiops gen. nov. and Geesops, none of which are considered by us to be particularly closely related to Phacops.

Morocops is a senior subjective synonym of Barrandeops and quite possibly paraphyletic. Future efforts should be focused on re-evaluations of morphologically similar taxa described previously in the literature. The majority of these come from Europe and are of peri-Gondwanan origin. Morocops is not known from Laurussia. The similarities between the stratigraphically earliest Geesops in the basal Eifelian of the French Ardennes and coeval species of Morocops in Morocco suggest that a descendant of the latter was first able to cross the Rheic Ocean during this time.

Adrisiops gen. nov. is erected for a group of species from upper Emsian to Eifelian strata in Morocco and upper Emsian strata in Algeria. As such the genus is possibly exclusively Gondwanan. The origin of Adrisiops gen. nov. and its relationship to other phacopines remains enigmatic and awaits further study. As the next step, more species of Adrisiops gen. nov. should be formally described as soon as new material becomes available for deposition in a museum collection.

\section{Acknowledgements}

We express our gratitude to Karsten Weddige and Rudy Lerosey-Aubril for allowing one of us $(\mathrm{AvV})$ to study type specimens housed in the Senckenberg Institute (Frankfurt am Main), to Martin Basse and Andries Weug for sharing photographs of trilobite specimens for comparison, to Mohamed Koumali for indispensable field support, to John Jagt for improving the manuscript, and to Barry van Bakel, Martin Basse, Euan Clarkson and René Fraaije for helpful discussions. The manuscript benefited from the constructive review comments provided by Brian Chatterton and Raimund Feist.

\section{References}

Aboussalam, Z.S., Becker, R.T. \& Bultynck, P. 2015. Emsian (Lower Devonian) conodont stratigraphy and correlation of the Anti-Atlas (Southern Morocco). Bulletin of Geosciences 90, 893-980. DOI 10.3140/bull.geosci.1534

Alberti, G.K.B. 1970. Trilobiten des jüngeren Siluriums sowie des Unter- und Mittel-Devons. II. Abhandlungen der Senckenbergischen Naturforschenden Gesellschaft 525, $1-233$.

Alberti, G.K.B. 1983. Trilobiten des jüngeren Siluriums sowie des Unter- und Mittel-Devons. IV. Senckenbergiana lethaea $64,1-88$.

Attems, C.M.T. von 1951. Myriopoden aus Höhlen des Belgischen Congo. Revue de zoologie et de botanique africaines 44, 386-404.

BARRANDE, J. 1852. Système Silurien du centre de la Bohęme. Ière partie. Recherches paléontologiques. I. Trilobites. $935 \mathrm{pp}$. Prague and Paris. DOI 10.5962/bhl.title.82327

BAsse, M. 1998. Trilobiten aus mittlerem Devon des Rhenohercynikums: III. Proetida (3), Phacopida (2), Lichida (Lichoidea, Odontopleuroidea) und ergänzende Daten. Palaeontographica (A) 249, 1-162.

Basse, M. 2006. Eifel-Trilobiten IV. Proetida (3), Phacopida (3). 304 pp. Quelle \& Meyer-Verlag, Wiebelsheim.

Basse, M. 2012. Fossilium Catalogus I: Animalia. Pars 150. Trilobites Africae: Catalogus typorum. 311 pp. Margraf Publishers $\mathrm{GmbH}$, Weikersheim.

Becker, R.T., Aboussalam, S.Z., Bockwinkel, J., Ebbighausen, V., El Hassani, A. \& NüBel, H. 2004a. Upper Emsian stratigraphy at Rich Tamelougou near Torkoz (SW Dra Valley, Morocco). Documents de l'Institut Scientifique, Rabat 19, 86-90.

Becker, R.T., Bockwinkel, J., Ebbighausen, V., Aboussalam, S.Z., El Hassani, A., NüBel, H. 2004b. Lower and Middle Devonian stratigraphy and faunas at Bou Tserfine near Assa (Dra Valley, SW Morocco). Documents de l'Institut Scientifique, Rabat 19, 91-101.

Becker, R.T., Jansen, U., Plodowski, G., Schindler, E., AbousSalam, S.Z. \& Weddige, K. 2004c. Devonian litho- and 
biostratigraphy of the Dra Valley - an overview. Documents de l'Institut Scientifique, Rabat 19, 5-20.

Bonino, E. \& Kier, C. 2010. The Back to the Past Museum Guide to Trilobites. 494 pp. Back to the Past Museum, Puerto Morelos.

Brett, C.E., Zambito, J.J., Schindler, E. \& Becker, R.T. 2012. Diagenetically-enhanced trilobite obrution deposits in concretionary limestones: The paradox of "rhythmic events beds". Palaeogeography, Palaeoclimatology, Palaeoecology 367/368, 30-43. DOI 10.1016/j.palaeo.2011.12.004

BronN, H. 1825. Ueber zwei neue Trilobiten-Arten zum Calymene-Geschlechte gehörig. Taschenbuch für die gesammte Mineralogie, 19(1), Zeitschrift für Mineralogie, Taschenbuch 1, 317-321.

Bruton, D.L. \& HAAS, W. 1997. Functional morphology of Phacopinae (Trilobita) and the mechanics of enrolment. Palaeontographica (A) 245, 1-43.

CampBell, K.S.W. 1977. Trilobites of the Haragan, Bois d'Arc and Frisco formations (Early Devonian), Arbuckle Mountains region, Oklahoma. Oklahoma Geological Survey Bulletin 123, $1-227$.

Chatterton, B.D.E. \& GibB, S.L. 2010. Latest Early to early Middle Devonian trilobites from the Erbenochile bed, Jbel Issoumour, southeastern Morocco. Journal of Paleontology 84, 1188-1205. DOI 10.1666/10-027.1

Chatterton, B.D.E., Fortey, R.A., Brett, K.D., Gibb, S.L. \& McKellaR, R.C. 2006. Trilobites from the upper Lower to Middle Devonian Timrhanrhart Formation, Jbel Gara el Zguilma, southern Morocco. Palaeontographica Canadiana 25, 1-177.

Chlupéč, I. 1971. New phacopid trilobites from the Devonian of Czechoslovakia. Časopis pro mineralogii a geologii 16, 255-261.

ChLuPÁČ, I. 1977. The phacopid trilobites of the Silurian and Devonian of Czechoslovakia. Rozpravy Ústředního ústavu geologického 43, 1-172.

Chlupáč, I. \& Kukal, Z. 1986. Reflection of possible global Devonian events in the Barrandian area, C.S.S.R. In WALLISER, O.H. (ed.) Global Bio-events: a critical approach. Lecture Notes in Earth Sciences 8, 169-179.

Crônier, C. \& Viersen, A.P. van. 2008. The 'Mur des douaniers', an exceptionally well preserved Early Eifelian fossil site. Bulletin de la Société géologique de France 179, 89-95. DOI 10.2113/gssgfbull.179.1.89

Dalman, J.W. 1826. Om palaeaderna, eller de sa kallade trilobiterna. Kongliga Svenska Vetenskaps-Akademien Handlingar 1826, 113-294.

Dorgan, K.M., Jumars, P.A., Johnson, B., Boudreau, B.P. \& LANDIS, E. 2005. Burrow extension by crack propagation. $\mathrm{Na}$ ture 433, 475. DOI 10.1038/433475a

Dresnay, R. Du, Hindermeyer, J., Emberger, A., Caia, J., Destombes, J. \& Hollard, H. 1988. Carte géologique du Maroc, Todrha - Ma'der (Anti-Atlas oriental, zones axiale et péripherique Nord et Sud) - Echelle: 1/200 000. Notes et Mémoires du Service géologique du Maroc 243.

Евасн, M.C. \& Ahyong, S.T. 2001. Phylogeny of the trilobite subgenus Acanthopyge (Lobopyge). Cladistics 17, 1-10. DOI 10.1111/j.1096-0031.2001.tb00107.x

EMmRich, H.F. 1839. De trilobitis: dissertatio petrefactologica quam consensu et auctoritate amplissimi philosophorum ordinis in alma litterarum universitate Friderica Guilelma pro summis in philosophia honoribus. 56 pp. Nietackian, Berlin.

Ghobadi Pour, M. 2015. Name change for the Devonian trilobite Cultrops Struve, 1995. Paläontologische Zeitschrift 89, 669-670. DOI 10.1007/s12542-015-0266-4

HaAs, W. 1968. Trilobiten aus dem Silur und Devon von Bithynien (NW-Türkei). Palaeontographica (A) 130, 60-207.

HAAs, W. 1969. Lower Devonian trilobites from central Nevada and northern Mexico. Journal of Paleontology 43, 641-659.

Hawle, I. \& CoRdA, A.J.C. 1847. Prodrom einer Monographie der böhmischen Trilobiten. 176 pp. Calve, Prague.

Holloway, D.J. 2013. The trilobite Cirriticeps gen. nov. (Proetida, Tropidocoryphidae) from the Silurian of New South Wales. Memoirs of the Association of Australasian Palaeontologists 44, 53-63.

Jansen, U., Becker, G., Plodowski, G., Schindler, E., Vogel, O. \& Weddige, K. 2004. Pragian and Emsian near Aouinet Torkoz (SW Dra Valley, Morocco). Documents de l'Institut Scientifique, Rabat 19, 75-84.

Jell, P.A. \& Adrain, J.M. 2002. Available generic names for trilobites. Memoirs of the Queensland Museum 48, 331-553.

Khaldi, A.Y., Crônier, C., Hainaut, G., Abbache, A. \& Ouali Mehadj, A. 2016. A trilobite faunule from the Lower Devonian of the Saoura Valley, Algeria: biodiversity, morphological variability and palaeobiogeographical affinities. Geological Magazine 153, 357-387.

DOI $10.1017 /$ S0016756815000345

Kielan, Z. 1954. Les trilobites mésodévoniens des monts de Sainte-Croix. Palaeontologia Polonica 6, 1-50.

Klug, C., Schulz, H. De Baets, K. 2009. Red Devonian trilobites with green eyes from Morocco and the silicification of the trilobite exoskeleton. Acta Palaeontologica Polonica 54, 117-123. DOI 10.4202/app.2009.0112

Le MAître, D. 1952. La faune du Dévonien inférieur et moyen de la Souara et des abords de l'Erg El Djemel (Sud Oranais). Matériaux pour la Carte géologique de l'Algérie. Ire série, paléontologie 12, 1-170.

Lespérance, P.J. \& Sheehan, P.M. 1987. Trilobites et brachiopods ashgilliens (Ordovicien supérieur) de l'«Assise» de Fosse, Bande de Sambre-Meuse (Belgique). Bulletin de l'Institut royal des Sciences naturelles de Belgique, Sciences de la Terre 57, 91-123.

Lieberman, B.S. \& KLOC, G.J. 1997. Evolutionary and biogeographic patterns in the Asteropyginae (Trilobita, Devonian) Delo, 1935. Bulletin of the American Museum of Natural History 232, 1-127.

McKellar, R.C. \& Chatterton, B.D.E. 2009. Early and Middle Devonian Phacopidae (Trilobita) of southern Morocco. Palaeontographica Canadiana 28, 1-109.

Morzadec, P. 1969. Révision de Phacops (Phacops) potieri Bayle 1878 (Trilobites). Bulletin de la Société géologique de France (7) 10, 917-923.

DOI 10.2113/gssgfbull.S7-XI.6.917

Morzadec, P. 1983. Trilobites du Dévonien (EmsienFamennien) de la rade de Brest (Massif armoricain). Palaeontographica (A) 181, 103-184.

Morzadec, P. 2001. Les trilobites Asteropyginae du Dévonien de l'Anti-Atlas (Maroc). Palaeontographica (A) 262, 53-85. 
Morzadec, P., Mergl, M., Villarroel, C., Janvier, P. \& Racheboeuf, P.R. 2015. Trilobites and inarticulate brachiopods from the Devonian Floresta Formation of Colombia: a review. Bulletin of Geosciences 90,331-358. DOI 10.3140/bull.geosci.1515

MülleR, P. 2005. Revision der Gattung Scabrella (Trilobita; Unter-Devon). Geologica et Palaeontologica 39, 1-27.

ÖZDikmEN, H. 2009. Nomenclatural changes for twenty trilobites genera. Munis Entomology \& Zoology 4, 155-171.

Pek, I. \& VANĚK, J. 1991. On some Silurian and Devonian trilobites of Bolivia. Acta Universitatis Palackianae Olomucensis Facultas Rerum Naturalium: Geographica-Geologica 103, 75-103.

PřibYl, A. \& ERBEn, H.K. 1952. Über einige neue oder wenig bekannte Acanthopyginae (Tril.) des böhmischen und des deutschen Devons. Paläontologische Zeitschrift 26, 141-174. DOI 10.1007/BF03224495

Schraut, G. 2000a. Trilobiten aus dem Unter-Devon des südöstlichen Anti-Atlas, Süd-Marokko. Senckenbergiana lethaea 79, 361-433.

Schraut, G. 2000b. Eine neue Unterart von Phacops (Phacops) sparsinodosus Struve 1970 aus dem Mittel-Devon von Marokko. Senckenbergiana lethaea 80, 525-535.

Schraut, G. \& Feist, R. 2004. The Devonian styginid trilobite Paralejurus, with new data from Spain and Morocco. Journal of Paleontology 78, 709-722. DOI 10.1666/0022-3360(2004)078<0709:TDSTPW>2.0.CO;2

SCoteSE, C.R. 2014. Atlas of Devonian Paleogeographic Maps, PALEOMAP Atlas for ArcGIS, volume 4, The Late Paleozoic, Maps 65-72, Mollweide Projection. PALEOMAP Project, Evanston, IL.

SMEenk, Z. 1983. Devonian trilobites of the southern Cantabrian Mountains (northern Spain) with a systematic description of the Asteropyginae. Leidse Geologische Mededelingen 52, 383-511.

Struve, W. 1970. Beiträge zur Kenntnis der Phacopina (Trilobita), 7: Phacops-Arten aus dem Rheinischen Devon. 1. Senckenbergiana lethaea 51, 133-189.

Struve, W. 1972. Beiträge zur Kenntnis der Phacopina (Trilobita), 8: Phacops-Arten aus dem Rheinischen Devon. 2. Untergattungs-Zuweisung. Senckenbergiana lethaea 53, 383-403.

Struve, W. 1976. Beiträge zur Kenntnis der Phacopina (Trilobita), 9: Phacops (Omegops) n. sg. (Trilobita; Ober-Devon). Senckenbergiana lethaea 56, 429-451.

Struve, W. 1982. Beiträge zur Kenntnis der Phacopina (Trilobita), 10: Neue Untersuchungen über Geesops (Phacopinae; Unter- und Mittel-Devon). Senckenbergiana lethaea 63, 473-495.

Struve, W. 1995. Beiträge zur Kenntnis der Phacopina (Trilobita), 18: Die Riesen-Phacopiden aus dem Maïder, SE-marokkanische Prä-Sahara. Senckenbergiana lethaea 75, 77-129.

Thomas, A.T. \& Holloway, D.J. 1988. Classification and phylogeny of the trilobite order Lichida. Philosophical Transac- tions of the Royal Society of London. Series B, Biological Sciences 321(1205), 179-262. DOI 10.1098/rstb.1988.0093

Viersen, A.P. van 2006. New Middle Devonian trilobites from Vireux-Molhain (Ardennes, northern France). Senckenbergiana lethaea $86,63-75$.

VIERSEN, A.P. vAN 2007. Preliminary report of trilobites from the Hanonet Formation (Eifelian - Givetian transition), southern border of the Dinant Synclinorium, Belgium. Bulletin de l'Institut royal des Sciences naturelles de Belgique, Sciences de la Terre 77, 15-29.

VIERSEN, A.P. VAN 2008. First record of the odontopleurid trilobite Koneprusia from the lower Eifelian of Vireux-Molhain (northern France), with remarks on the associated trilobite fauna. Geologica Belgica 11, 83-91.

VIERSEN, A.P. vAN 2013. Latest Early to early Middle Devonian acastid trilobites from the eastern part of the Dinant Synclinorium, Belgium (Rhenohercynian Zone), 1-10. In Holloway, D.J. \& Laurie, J. (eds) Siluro-Devonian Studies. 2. Memoirs of the Association of Australasian Palaeontologists 44.

Viersen, A.P. van 2015. Trilobites du Dévonien des Ardennes (zone rhéno-hercynienne): biostratigraphie, évolution et événements. Fossiles, Revue française de Paléontologie 11, $5-24$.

Viersen, A.P. van \& Holland, D. 2016. Morphological trends and new species of Cyphaspis (Trilobita, Otarioninae) in the Devonian of Morocco, Turkey, Germany and Belgium. Geologica Belgica 19, 251-271. DOI 10.20341/gb.2016.008

Viersen, A.P. van \& Prescher, H. 2009. Trilobites from the Longlier Formation (Lower Devonian; Neufchâteau Synclinorium, southeast Belgium): first record of Pragian associated "Rhenish" and "Bohemian" assemblages from the Ardennes. Bulletin de l'Institut royal des Sciences naturelles de Belgique, Sciences de la Terre 79, 5-26.

Viersen, A.P. van, Prescher, H. \& SAvelsbergh, J. 2009. Description of two new trilobites from the Ahrdorf Formation (Middle Devonian) at the "Trilobitenfelder" of Gees, Eifel, Rhenish Mountains. Bulletin de l'Institut royal des Sciences naturelles de Belgique, Sciences de la Terre 79, 43-53.

Viersen, A.P. van, Taghon, P. \& Magrean, B. in press. The phacopid trilobites Austerops McKellar \& Chatterton, 2009, Hottonops gen. nov. and Loreleiops gen. nov. from the Devonian of the Ardenno-Rhenish Mountains. Neues Jahrbuch für Geologie und Paläontologie, Abhandlungen 283.

Wright, A.J. \& HAAS, W. 1990. A new Early Devonian spinose phacopid trilobite from Limekilns, New South Wales: morphology, affinities, taphonomy and palaeoenvironment. Records of the Australian Museum 42, 137-147.

DOI 10.3853/j.0067-1975.42.1990.111

Whittington, H.B. \& Kelly, S.R.A. 1997. Morphological terms applied to Trilobita, 313-329. In KAESLER, R.L. (ed.) Treatise on invertebrate paleontology, Part O, Arthropoda 1. Trilobita, revised. Volume 1: Introduction, Order Agnostida, Order Redlichiida. Geological Society of America, Boulder, Colorado and University of Kansas Press, Lawrence, Kansas. 